\title{
Enhancing Organizational Citizenship Behavior of Teacher in Pre-School
}

\author{
Griet Helena Laihad ${ }^{1}$, Bedjo Sujanto², I Made Putrawan ${ }^{3}$ \\ Jakarta State University, Jakarta, Indonesia \\ 'helena@yahoo.com, ${ }^{2}$ bejo@yahoo.com, ${ }^{3}$ made@yahoo.com
}

\begin{abstract}
Organizational citizenship behavior (OCB) has received much attention in the past decade as scholars have recognized its significant impact on the success of organizations. The current research seeks to enrich our understanding of citizenship behavior in the pre-school setting by identifying the main factors that may enhance this behavior among teachers. Specifically, the research objectives are to determine the influence of organizational culture, leadership style and decision making toward organizational citizenship behavior of teacher in pre-school. The research was conducted sampling to 175 respondent teachers of pre-school at Kota Bogor with path analysis design. The results indicate that: first, organizational culture has direct influence toward organizational citizenship behavior of the teacher in pre-school. Second, leadership Style has direct influence toward organizational citizenship behavior of the teacher in pre-school. Third, decision making has direct influence toward organizational citizenship behavior of the teacher in pre-school. Fourth, organizational culture has direct influence toward decision making. The fifth, leadership style has direct influence toward decision making. The result of the study contributes to our understanding of the way organization culture, leadership style, decision making and OCB interact in pre-school. Furthermore, the conclusion in enhancing organizational citizenship behavior of teacher pre-school would be strengthening on organizational culture, leadership style, and decision making.
\end{abstract}

Keywords: Organizational citizenship behavior, organizational culture, leadership style and decision making.

\section{INTRODUCTION}

The education fundamental begins from early childhood and this term often called the golden age in which all the functions and capabilities of the children are growing very rapidly require the contribution of adults to provide appropriate stimulation to their ability to be actualized and optimally developing (Vygotsky). This indicates the importance function of teachers in carrying out their duties not only in pedagogic competence but also with personality and social competence. The maximum contribution of teachers can be achieved if they continue to develop themselves through formal and informal education and in social behaviors such as cooperation, assisting each other, tolerance with students, coworkers and leaders by applying the principles and spirit of togetherness. By having the above behavior, the teacher can be interpreted to have organizational citizenship behavior (OCB), which is the benefit for the progress of the school.

Based on the data from the Ministry of Education and Culture of the Republic of Indonesia, Directorate General of PAUDNI (April 2013), only 20.51\% pre-school teachers have passed the graduate. It means $79.49 \%$ teacher below that standard. The results of initial survey in the province of Banten (2012) and Bogor (2012) concern OCB indicators such as carry out the task are more than expected (voice), speaking up and offering constructive suggestions for change (voice), representing the organization in a positive way when away from school is still below $50 \%$. It can be interpreted that the OCB of teachers is low than expected and not maximized. Based on the above, the researcher is interested in taking on the issue: "Is there an effect of organizational culture, leadership style and decision making toward organizational citizenship behavior of teacher in pre-school?"

\section{LITERATURE REVIEW}

OCB is one of the main topics that get practitioners and researchers attention and interests. Many studies have been done to identify the factors that enhance OCB. Organizational Citizenship Behavior was first defined by organs (1997.86) as individual behavior that is discretionary, not directly or explicitly recognized by the formal reward system, and that is in the aggregate promotes the effective 
functioning of the organization. According to Mcshane \& Glinow (2008:38), one of the defining characteristics of engaged employees is that they perform beyond task performance standard or expectations. They will go the extra step, or maybe even the extra mile, to support the interest of organizations. Furthermore, OCB is defined by many experts e.q. Colquitt et al (2008: 43-44) who basically has the same meaning as voluntary employee activities that may or may not be a reward but that contribute to the organization by improving the overall quality of the setting in which work takes place.

The Factors affecting teachers' OCB include Organizational Culture, leadership style, and decisionmaking. Organizational culture according to Ivancevich et al (2006: 44) is what the employees perceive and how that perception creates a pattern of beliefs, values, and expectations. Moreover, Owen (2006:166) defines organizational culture as the body of solutions to external and internal problems that have worked consistently for a group and that is, therefore, taugh to new members as the correct way to perceive, think about and feel in relation to those problems. Established communication patterns-oriented full of intimacy and the mutual interests will create a conducive atmosphere in the school so that the teachers will be happy to assist co-workers who have difficulty in carrying out their duties and co-workers are able to tolerate different of views.

Mullins (2007:721) defined leadership style as the way in which the functions of leadership are carried out, the way in which the manager typically behaves toward member of the group. According to Goetsch \& Davis (2000:251), leadership style has to do with how people interact with those they seek to lead. Principals who have a democratic leadership style in which decision-making is not only unilateral but also involve teachers in each activity and provide the appropriate authority with the capacity will increase positive behavior of teachers such as OCB.

Decision-making according to Certo (1997: 6) is a process of choosing the best alternative for reaching objectives. Teachers were able to determine the best option for achieving the goal will realize the importance of developing the OCB for the betterment of the school.

\section{METHODOLOGY}

This study used a quantitative approach with survey method and path analysis (path analysis) to analyze the influence of one variable to another variable. There are three exogenous variables, organizational culture (X1), leadership style (X2) and decision making (X3) for OCB, and two endogenous variables, decision-making (X3) and OCB (Y).

The population in this study is an accredited private preschool teachers in the six areas of Bogor city. Based Slovin's sampling method, obtained a sample of 175 people. Sampling technique is using proportional random sampling and data collection techniques are using instruments such as questionnaires with test and non-test. The validity test is using Product Moment and biserial point. The reliability test is using Cronbach alpha .The model is observable on Figure 1. Below:

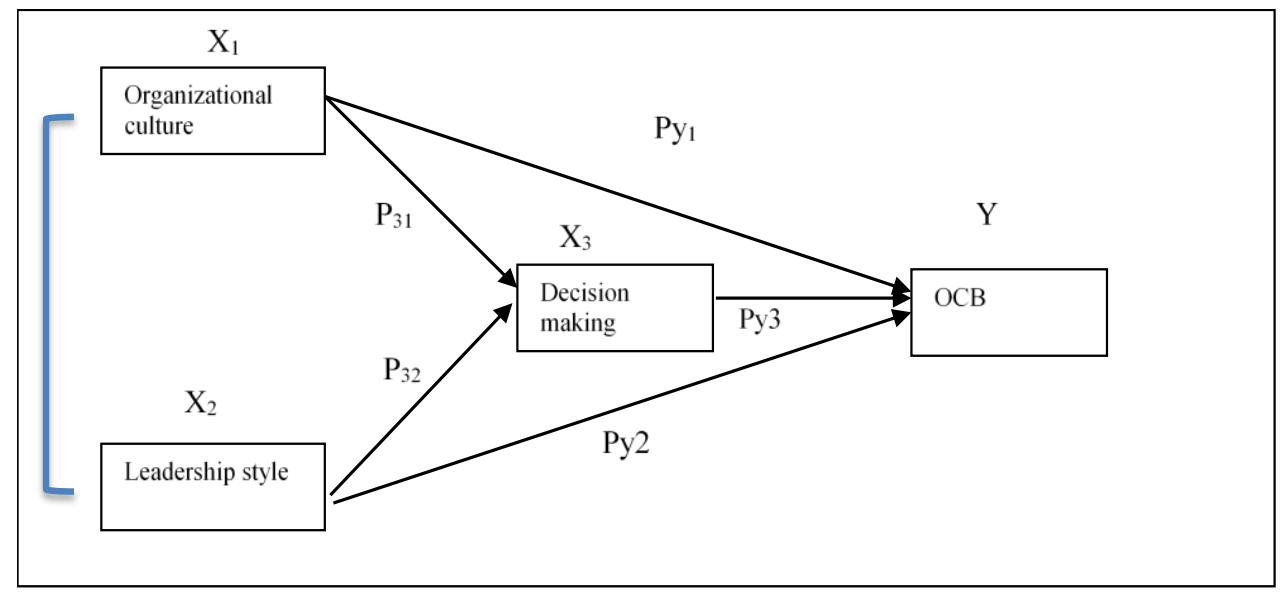

Figure1. Research design with the path analysis

Descriptive statistical method has been used to describe the data. Data analysis techniques include: (a) a description of the data, presented in the frequency table and histogram diagram, (b) normality test using Lilliefors test, and linearity test and regression significance test using the F test, (c) test the research hypothesis. 
Path analysis is used to determine (1) the direct positive influence of organizational culture toward $\mathrm{OCB},(2)$ direct positive influence of leadership style toward OCB, (3) direct positive influence on decision making toward $\mathrm{OCB},(4)$ the direct positive influence of organizational culture on decision making, (5) direct positive influence of leadership style toward decision making.

\section{RESULT AND DISCUSSION}

The finding of this study revealed that organizational culture, leadership style and decision making had a positive influence on organizational citizenship behavior as follow;

In first structural, as depicted in Table 1 , Organizational culture $\left(\mathrm{X}_{1}\right)$ had direct positive significant influence toward decision making $\left(\mathrm{X}_{3}\right)$ with regression coefficient $=0.419(\mathrm{t}=5.710 ; \mathrm{p}<0,01)$, while Leadership style $\left(\mathrm{X}_{2}\right)$ had direct positive effect toward decision making with regression coefficient $0.256(\mathrm{t}=3.485 ; \mathrm{p}<0.01)$. Coefficient of Determination $\mathrm{X}_{2}$ to $\mathrm{X}_{1}$ derived is 0.361(Table. 2).

Table1. Path coeficient of the first structural model

\begin{tabular}{|c|c|c|c|c|c|c|}
\hline \multirow{2}{*}{\multicolumn{2}{|c|}{ Model }} & \multicolumn{2}{|c|}{ Unstandardized Coefficients } & Standardized Coefficients & \multirow[t]{2}{*}{$\mathrm{t}$} & \multirow[t]{2}{*}{ Sig. } \\
\hline & & $\mathrm{B}$ & Std. Error & Beta & & \\
\hline \multirow[t]{3}{*}{1} & (Constant) & 2.980 & 2.273 & & 1.311 & .192 \\
\hline & $\mathrm{X}_{1}$ & .118 & .021 & .419 & 5.710 & .000 \\
\hline & $\mathrm{X}_{2}$ & .071 & .020 & .256 & 3.485 & .001 \\
\hline
\end{tabular}

Table2. Summary of first structural model

\begin{tabular}{|l|l|l|l|l|}
\hline Model Summary \\
\hline Model & $\mathrm{R}$ & $\mathrm{R}$ Square & Adjusted R Square & Std. Error of the Estimate \\
\hline 1 & $.601^{\mathrm{a}}$ & .361 & .353 & 2.70245 \\
\hline a. Predictors: (Constant), $\mathrm{X}_{2}, \mathrm{X}_{1}$ \\
\hline
\end{tabular}

In the second structural model, as depicted in Table 3, organizational culture $\left(\mathrm{X}_{1}\right)$ had direct positive significant influence toward OCB $(\mathrm{Y})$ about $=0.206(\mathrm{t}=2.968 ; \mathrm{p}<0,01)$. Leadership style $\left(\mathrm{X}_{2}\right)$ had direct positive influence toward OCB about $0.440(\mathrm{t}=6.668 ; \mathrm{p}<0.01)$. Decision making $\left(\mathrm{X}_{3}\right)$ has direct positive significant influence toward OCB about $0.210(\mathrm{t}=3.179 ; \mathrm{p}<0.01)$ with coefficient of determination $=0.521$ (Table 4).

Table3. Path coefisien of the second structural model

\begin{tabular}{|c|c|c|c|c|c|c|}
\hline \multirow{2}{*}{\multicolumn{2}{|c|}{ Model }} & \multicolumn{2}{|c|}{ Unstandardized Coefficients } & \multirow{2}{*}{$\begin{array}{l}\text { Standardized Coefficients } \\
\text { Beta }\end{array}$} & \multirow[t]{2}{*}{$\mathrm{t}$} & \multirow[t]{2}{*}{ Sig. } \\
\hline & & B & Std. Error & & & \\
\hline \multirow[t]{4}{*}{1} & (Constant) & 33.317 & 6.750 & & 4.936 & .000 \\
\hline & $\mathrm{X} 1$ & .197 & .066 & .206 & 2.968 & .003 \\
\hline & $\mathrm{X} 2$ & .415 & .062 & .440 & 6.668 & .000 \\
\hline & $\mathrm{X} 3$ & .716 & .225 & .210 & 3.179 & .002 \\
\hline
\end{tabular}

Table4. Summary of secondary structural model

\begin{tabular}{|l|l|l|l|l|}
\hline \multicolumn{4}{|l|}{ Model Summary } \\
\hline Model & R & R Square & Adjusted R Square & Std. Error of the Estimate \\
\hline 1 & $.722^{\mathrm{a}}$ & .521 & .512 & 7.98646 \\
\hline \multicolumn{2}{|l|}{ Predictors: (Constant), X3, X2, X1 } & \\
\hline
\end{tabular}

To sum up, the goodness of fit of the model is presented in Figure 2.

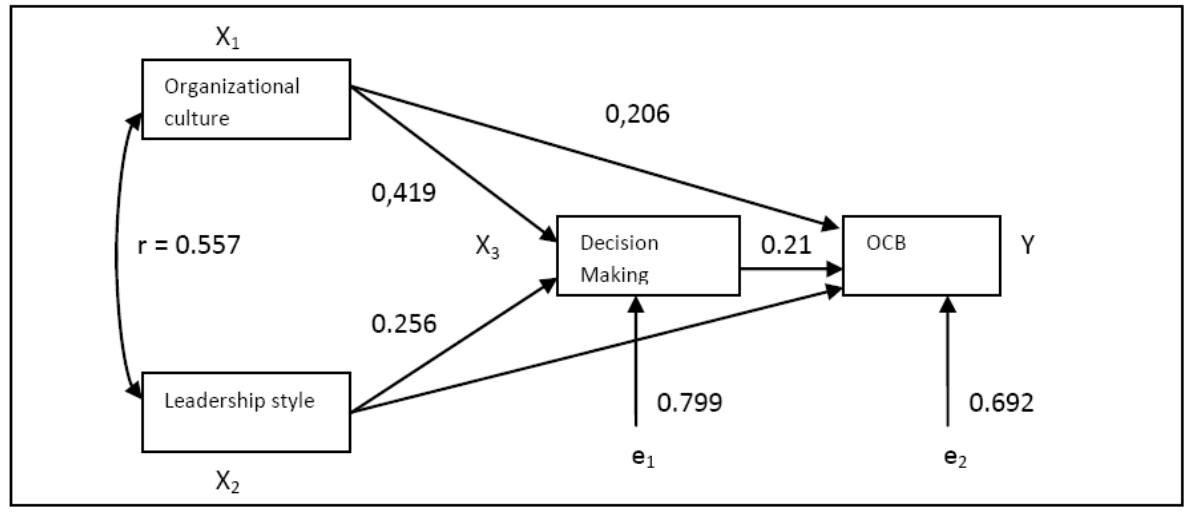

Figure2. Goodness of Fit Model 
Based on above model, it can be described that the organizational culture had direct positive influence toward decision making and the leadership style had direct positive influence toward decision making with $\mathrm{X}_{3}=0.419 \mathrm{X}_{1}+0.256 \mathrm{X}_{2}+0.799_{\mathrm{e}}$; with coefficient of determination $\left(\mathrm{R}_{2}\right)=$ 0.361. Therefore, it can be said that decision making of teachers in pre-school increased because of the effect of increasing organizational culture and leadership style. It is also be said that $36 \%$ of the variance in decision making originates from organizational culture and leadership style when the determination coefficient $\left(R_{2}=0.361\right)$ is taken into consideration.

Furthermore, organizational culture had direct positive influence toward OCB pre-school teacher, the leadership style had direct positive influence toward $\mathrm{OCB}$, and decision making had direct positive influence toward OCB with $\mathrm{Y}=0.206 \mathrm{X}_{1}+0.799 \mathrm{X}_{2}+0.21 \mathrm{X}_{3}+0,692_{\mathrm{e} 2}$; with coefficient of determination $\left(\mathrm{R}_{2}\right)=0.521$. Therefore, it can be said that organizational citizenship behavior of teachers in pre-school increased because of the effect of increasing organizational culture, leadership style, and decision making. It is also be said that $52 \%$ of the variance in OCB pre-school teacher originates from organizational culture, leadership style, and decision making when the determination coefficient $\left(R_{2}=0.521\right)$ is taken into consideration.

According to the result of the organizational culture such as safety culture, attention to detail and sociability, have an influence on organizational citizenship behavior. The result also showed that leadership style such as democratic style has an influence on organizational citizenship behavior.

\section{Conclusion}

This research proved that organizational culture, leadership style, and decision making, have a positive direct influence toward organizational citizenship behavior of teacher in pre-school. Although there have been different approaches and research findings on organizational culture, leadership style and decision making toward $\mathrm{OCB}$, it is more likely for the teachers who have unique culture, leadership style and decision making in their school to perform OCB better because teachers attitudes affect their behavior. Thus positive attitudes are expected to result in positive behaviors. These positive behaviors will also improve the performance of teachers and bring out positive results for their school. Therefore, it is quite important for the school to be aware of the factors that will affect its teachers' OCB. Positive organizational culture, leadership style, and decision making will increase positive OCB. This subject is even more important for education organizations where extra role behaviors of teachers are much more required. Any extra behavior of the teachers will increase contribution to education in return. Considering the research findings, it can be pointed out that in enhancing organizational citizenship behavior of teacher in pre-school would be strengthening the organizational culture, leadership style, and decision making.

\section{REFERENCES}

Colquitt, J A, Jeffery A. Lepine \& Michael J. Wesson. Organizational Behavior: Improving Performance and Commitment in the Workplace. New York: McGraw-Hill, 2009.

Certo S. Modern Management. Prentice-Hall International, Inc.1997.

Goetsch D.L \& Stanley B. Davis. Quality Management: Introduction to Total Quality Management for Production, Processing, and Services. New Jersey; Prentice Hall, Inc, 2000.

Greenberg, J. \& R. A. Baron. Behavior in Organizations. New Jersey: Pearson, 2008.

Ivancevich J.M, Robert Konopaske, Michael T. M. Organizational Behavior, and Management. New York, McGraw-Hill, 2008.

Mullins, L.J. Management and Organisational Behaviour. England, Pearson Educationa Limited, Prentice Hall, 2007.

McShane, S. L. \& M. A. Von Glinow. Organizational Behavior. New York: McGraw-Hill, 2008.

Organ, Dennis W. Organizational Citizenship Behavior: It's Construct Clean-up Time. School of Business Indiana University, 1997.

Owens Robert G. Organizational Behavior in Education: Adaptive Leadership and School Reform. Boston: Alyn an Baccon, 2006.

Robbins, S. P. \& T. A. Judge. Organizational Behavior. New Jersey: Pearson Education, 2009.

Santrock J.w. Psikologi Pendidikan. Dallas, McGraw-Hill 2007.

Kementrian Pendidikan dan Kebudayaan Republik Indonesia Direktorat Jenderal Pendidikan Anak

Usia Dini. Sosialisasi dan koordinasi program pembinaan PAUDNI. Jakarta, 2013.

Undang-Undang Republik Indonesia Nomor 14 Tahun 2005 tentang Guru dan Dosen. 